\title{
Nonphosphorylated Tau Protein Measurement
}

National Cancer Institute

\section{Source}

National Cancer Institute. Nonphosphorylated Tau Protein Measurement. NCI

Thesaurus. Code C84811.

The determination of the amount of nonphosphorylated Tau protein present in a sample. 